\title{
SISTEM NAVIGASI MAKLUK HIDUP: MENAKISME PENJELAJAHAN SECARAALAMIAH (IMPLEMENTASI STRATEGI PEMBELAJARAN TEMATIK PADA MATERI INDUKSI ELEKTROMAGNETIK)
}

\author{
Sabar Nurohman ${ }^{1}$, Sarwanto $^{2}$ \\ ${ }^{I}$ Mahasiswa Program Doktor Pendidikan IPA Universitas Sebelas Maret Jl. Ir. Sutami No.36A, Jebres, Surakarta, Indonesia \\ 57126 \\ E-mail: sabar_nurohman@student.uns.ac.id \\ ${ }^{2}$ Program Studi Pendidikan Fisika, Fakultas Keguruan dan Ilmu Pendidikan, Universitas Sebelas Maret, Jl. Ir. Sutami \\ No.36A, Jebres, Surakarta, Indonesia 57126 \\ Email : sarwanto@fkip.uns.ac.id
}

Diajukan: 3 Agustus 2020; Diterima: 2 September 2020; Diterbitkan: 31 Oktober 2020

\begin{abstract}
Abstrak: Kompetensi Dasar 3.6 Kelas IX memberi tantangan bagi guru sains untuk mengelaborasi konsep sains secara terpadu. Pada kompetensi dasar tersebut konsep fisika tentang elektromagnetisme digabungkan dengan konsep biologi tentang sistem navigasi. Melalui studi literatur terhadap berbagai jurnal ilmiah, artikel ini bertujuan untuk mengkaji bagaimana konsep listrik dan magnet memiliki peran penting dalam peristiwa pergerakan/navigasi beberapa jenis hewan. Kajian ini juga diperluas terhadap hewan-hewan yang melakukan navigasi menggunakan gelombang bunyi. Secara lebih terperinci, tujuan artikel ini adalah untuk menganalisis bagaimana mekanisme berbagai jenis hewan melakukan migrasi dikaitkan dengan beberapa konsep fisika berupa kelistrikan, kemagnetan, dan gelombang bunyi.
\end{abstract}

Kata kunci: Sistem navigasi, elektromagnetisme, gelombang bunyi

Abstract: Basic Competence 3.6 Class IX presents a challenge for science teachers to elaborate science concepts in an integrated manner. In these basic competencies, the physics concept of electromagnetism is combined with the biological concept of navigation systems. Through literature studies of various scientific journals, this article aims to examine how the concepts of electricity and magnetism have an important role in the movement/navigation of several types of animals. This study was also extended to animals that navigate using sound waves. In more detail, the purpose of this article is to analyze how the mechanism by which various types of animals migrate is related to several physical concepts in the form of electricity, magnetism, and sound waves.

Keywords: Navigation system, electromagnetism, sound waves

\section{Pendahuluan}

Salah satu Kompetensi Dasar (KD) pada mata pelajaran IPA SMP/MTs adalah: "Menerapkan konsep kemagnetan, induksi elektromagnetik, dan pemanfaatan medan magnet dalam kehidupan sehari-hari termasuk pergerakan/navigasi hewan untuk mencari makanan dan migrasi". KD tersebut muncul pada jenjang kelas IX dengan nomor 3.6. Secara ringkas dapat disebut sebagai KD 3.6 Kelas IX. KD 3.6 tersebut tampak secara eksplisit mengintegrasikan beberapa konsep fisika dan biologi secara bersamaan. Jika diidentifikasi, pada KD tersebut terdapat konsep fisika yaitu kemagnetan, dan induksi elektromagnetik. Selain itu juga muncul konsep biologi yaitu pergerakan/navigasi hewan dan migrasi. Secara implisit KD tersebut juga mengangkat konsep kimia yaitu protein fotoreseptif dan electroreseptor. Secara tradisional, implementasi KD tersebut dapat dilakukan dengan model pembelajaran IPA terpadu dalam rumpun "Within single Discipline" merujuk pada Fogarty dan Pete (2010). Tabel 1. Menyajikan teknik memadukan IPA dari cabang Fisika dan Biologi dengan model Within Single Discipline. Secara konseptual, KD 3.6 Kelas IX mengarahkan kita untuk menyajikan pembelajaran sains yang mengakar pada peristiwa nyata dalam kehidupan sehari-hari, yaitu peristiwa pergerakan, navigasi dan migrasi mahluk hidup. Berbagai jenis mahluk 
hidup terutama hewan memiliki kebiasaan untuk melakukan migrasi dari satu tempat ke tempat lain. Terkadang proses migrasi tersebut menempuh jarak yang sangat jauh, yaitu antar benua. Migrasi yang dilakukan oleh berbagai jenis burung merupakan respons atas kondisi habitat yang tertutup salju. Saat memasuki musim dingin, burung yang tinggal di bumi bagian utara (Eropa) melakukan perjalanan ke bumi bagian selatan, seperti Selandia Baru dan Australia, kemudian kembali lagi ke utara setelah musim dingin untuk berkembang biak.

Tabel 1. Model Keterpaduan Within single Discipline pada Kurikulum IPA Indonesia

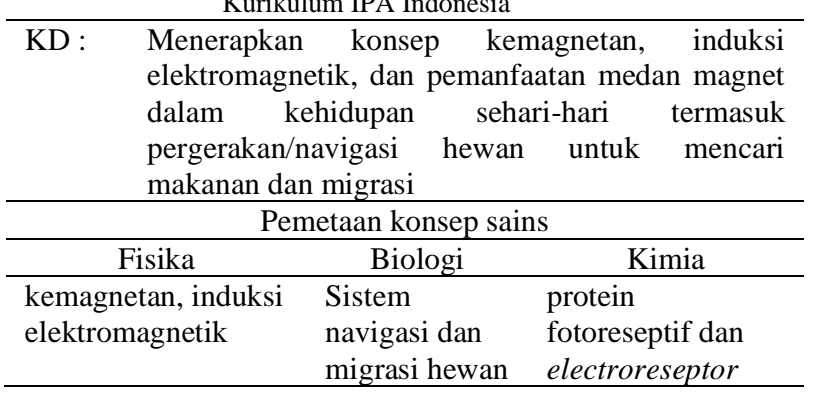

Selain fenomena migrasi, beberapa jenis hewan juga memiliki tradisi yang unik dalam mencari mangsa, dan mengetahui keadaan di sekitarnya. Ikan Hiu tidak mengandalkan mata untuk mencari mangsa. Hal yang sama juga terjadi pada kelelawar. Kelelawar, binatang nocturnal yang aktivitasnya dilakukan pada malam hari, bisa terbang dengan sangat lincah. Padahal seperti yang diketahui, mata kelelawar telah mengalami disfungsi sehingga tidak bisa digunakan untuk melihat. Setelah menguarai berbagai konsep yang terdapat pada KD 3.6 Kelas IX, dapat diusulkan sebuah strategi pembelajaran tematik dengan tema "Sistem Navigasi". Gambar 1 menunjukan peta konsep untuk tema sistem navigasi.

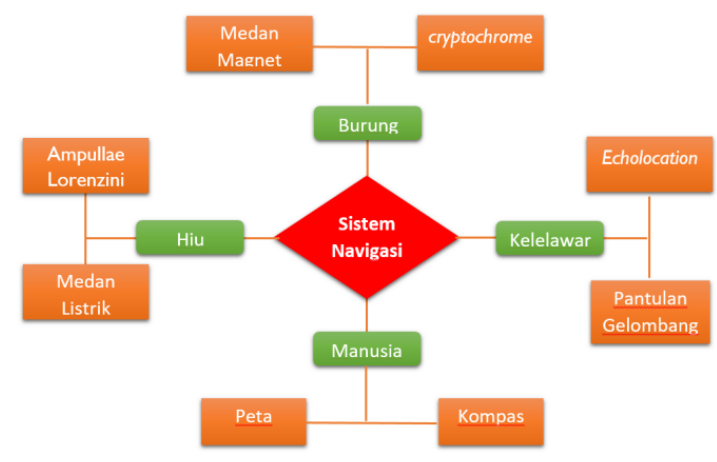

Gambar 1. Peta Konsep Untuk Tema Sistem Navigasi
Berdasarkan peta konsep sistem navigasi, pertanyaan yang dapat digunakan sebagai pemantik kegiatan pembelajaran adalah: 1) Bagaimana mekanisme burung dapat menjelajah benua? 2) Bagaimana ikan hiu mencari mangsa tanpa mengendalikan indra penglihatan? 3) Bagaiman kelelawar dapat mengenali lingkungan padahal mata kelelawar mengalami disfungsi?

\section{Landasan Teori}

\section{Medan Magnet}

Medan magnet adalah ruangan disekitar benda-benda yang bersifat magnet sehingga masih terpengaruh oleh gaya magnet (Young \& Freedman, 2016). Suatu kenyataan bahwa indra kita tidak dapat secara langsung mengamati adanya medan magnet, jadi adanya medan magnet dapat digambarkan dengan garis gaya magnet. Garis gaya magnet adalah garis khayal yang keluar dari kutub utara magnet dan masuk di kutub selatan magnet. Garis-garis ini berfungsi untuk membantu memvisualisasikan medan magnet yang ada disekitar magnet. Garis gaya magnet selalu mengarah dari kutub utara ke kutub selatan dan tidak pernah berpotongan seperti yang ditunjukan Gambar 2.

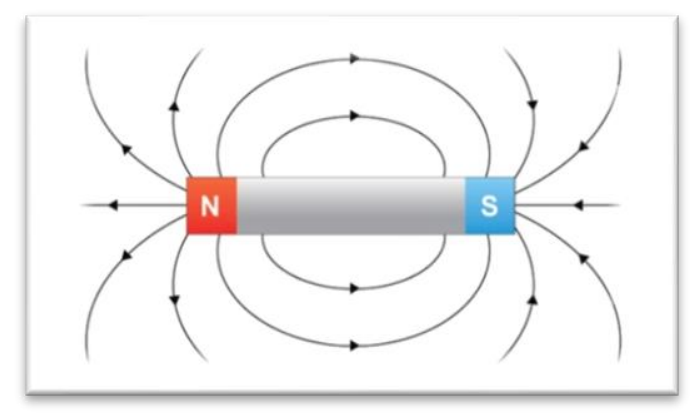

Gambar 2. Garis Gaya Magnet

\section{Medan Magnet Bumi}

Saat kita meletakan kompas, jarum pada kompas selalu menunjuk ke arah utara. Jika dikaitkan dengan konsep garis gaya magnet, hal ini menunjukan bahwa di atas permukaan bumi terdapat medan magnet yang mempengaruhi jarum pada kompas menunjuk pada arah utara. Medan magnet tersebut dikenal sebagai magnetosfer (medan magnet Bumi). Medan magnet bumi adalah medan vektor tiga dimensi yang berada dari permukaan bumi 
sampai ke atmosfer. Medan tiga dimensi tersebut biasanya dijelaskan dengan besarnya intensitas (besarnya vektor), sudut kemiringan (sudut antara vektor dan bidang horizontal lokal), dan deklinasi (perbedaan antara kutub magnetik dan geografis bumi) (Brian K. Taylor, 2016).

Medan magnet bumi dihasilkan dari arus listrik yang bersirkulasi di dalam inti bumi bagian luar yang berisi besi cair (Dormy, 2006). Inti bumi terdiridari dua bagian, yakni inti dalam (inner core) dan inti luar (outer core). Pada inti bumi bagian luar (outer core) terdapat berbagai logam cair yang bergerak mengelilingi inti dalam bumi (inner core) seperti ditunjukan Gambar 3. Selama mengelilingi inti dalam, logam cair tersebut mengalami ionisasi. Dengan demikian aliran material inti luar bumi bisa diibaratkan seperti aliran arus listrik. Sebagaimana yang ditemukan oleh Orstead, arus listrik yang mengalir akan menghasilkan medan magnet. Aliran listrik pada inti bumi juga akan menghasilkan medan magnet yang keluar dari kutub selatan bumi menuju ke kutub utara bumi.

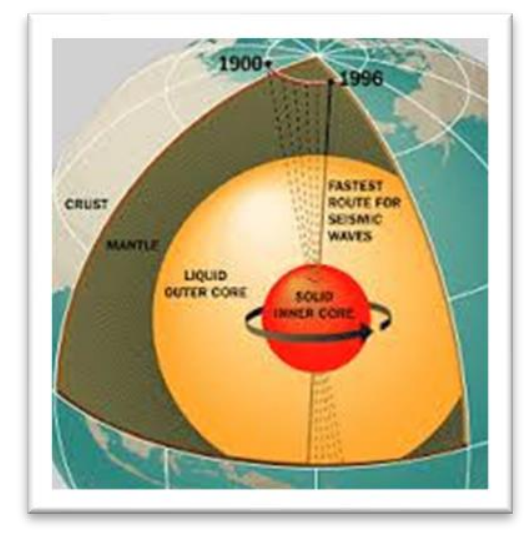

Gambar 3. Arus material cair pada Inti Luar Bumi

Pada kutub selatan bumi terdapat kutub utara magnet bumi, sedangkan pada kutub utara bumi terdapat kutub selatan magnet. Namun sebenarnya posisi kutub magnet bumi tidak benar-benar berimpit dengan kutub geografis bumi. Misalnya, kutub utara magnet bumi berada kira-kira $10^{\circ}$ dari kutub selatan bumi (Gambar 4). Oleh karena itu, jika kita meletakan kompas, maka jarum kompas akan menunjuk ke arah uatara. Karena jarum kompas menunjuk ke arah utara, maka dapat disimpulkan bahwa di bagian bumi sebelah selatan (kutub selatan bumi) terdapat kutub utara magnet.

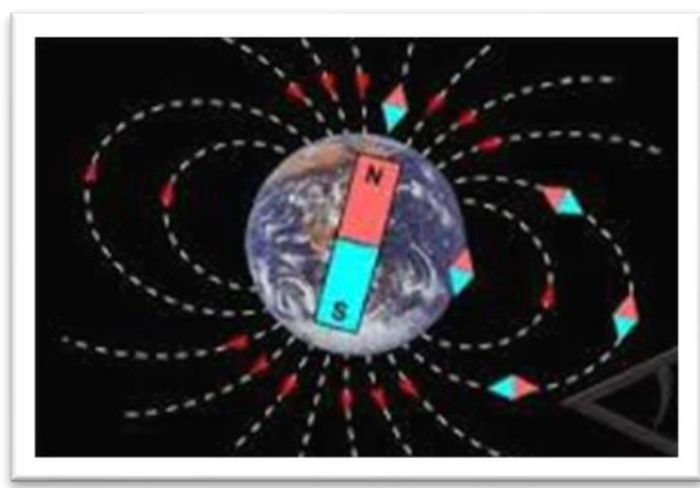

Gambar 4. Arah Medan Magnet Bumi

\section{Induksi Elektromagnetik}

Setelah Oersted menemukan bahwa arus listrik dapat menimbulkan medan magnet, maka berikutnya Michael Faraday dan Yoseph Henry secara terpisah menemukan fenomena yang sangat luas aplikasinya. Michael Faraday penasaran, jika arus listrik dapat menimbulkan medan magnet, apakah berlaku sebaliknya, bahwa medan magnet dapat menghasilkan arus listrik. Untuk mencari jawabannya, maka Faraday merancang sebuah percobaan seperti ditunjkan pada gambar 5 .

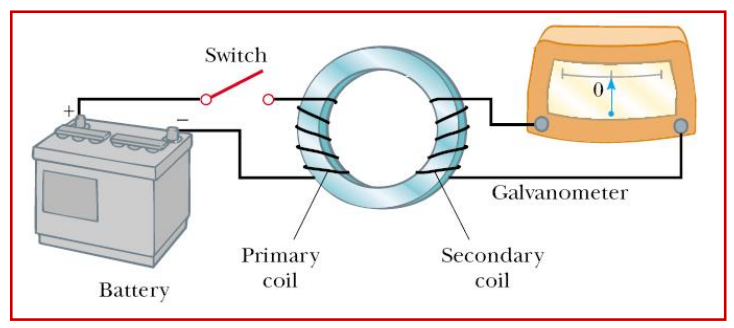

Gambar 5. Desain Percobaan Faraday (Serway \& Jewett, 2004)

Instrumen percobaan terdiri dari sebuah inti besi yang berbentuk lingkaran (donat), kemudian pada sisi kiri dan sisi kanannya diberi lilitan konduktor. Lilitan yang sebelah kiri (disebut sebagai kumparan primer) dihubungkan dengan sumber tegangan (DC), sedangkan lilitan sebelah kanan (disebut sebagai kumparan skunder) dihubungkan dengan galvanometer. Faraday berharap, ketika saklar pada kumparan primer ditutup, -pada saat itu inti besi akan mengandung medan magnet- maka medan magnet pada inti besi dapat menginduksi kumparan skunder sehingga 
pada kumparan skunder akan muncul arus listrik yang ditandai adanya gerakan pada galvanometer.

Namun kenyataannya tidaklah demikian. Pada saat saklar dalam keadaan tertutup, tidak dijumpai adanya arus listrik pada kumparan skunder. Kemudian, pada saat faraday memutus saklar, dia mengamati jarum galvanometer bergerak sebentar kemudian diam lagi, begitupun pada saat saklar ditutup kembali, galvanometer bergerak sebentar kemudian diam lagi. Jika saklar dibuat On-Off terus menerus secara bergantian maka dia melihat bahwa jarum galvanometer akan terus bergerak bolak-balik.

\section{Metode Penelitian}

Melalui percobaan ini dapat disimpulkan bahwa arus listrik dapat dihasilkan dengan cara memaparkan medan magnet yang terus berubah setiap saat pada suatu koil/kumparan. Selain itu, melalui percobaan tersebut manusia kemudian mengenal adanya arus listrik bolakbalik (AC). Berdasarkan percobaan Faraday, diformulasikan sebuah Hukum sebagai berikut: "Besar Gaya Gerak Listrik (GGL) pada sebuah kumparan sebanding dengan kecepatan perubahan medan magnet yang memapar pada kumparan secara tegak lurus (Hukum Faraday)" (Serway \& Jewett, 2004). Secara matematis dapat dituliskan:

$$
\varepsilon=-N \frac{\Delta(B \bullet A)}{\Delta t}=-N \frac{\Delta(B A \cos \theta)}{\Delta t}
$$

$\varepsilon \quad$ : Gaya Gerak Listrik (V)

$\mathrm{N}$ : Jumlah lilitan pada kumparan

B : Medan Magnet

A : Luas permukaan kumparan

$\Delta \mathrm{t}:$ Perubahan waktu

Berdasarkan persamaan tersebut dapat disimpulkan bahwa besar GGL induksi ditentukan oleh: 1) Banyaknya lilitan pada kumparan, 2) Perubahan besarnya medan magnet tiap satuan waktu, 3) Perubahan luas penampang kumparan yang terpapar medan magnet tiap satuan waktu, 4) Luas daerah tertutup oleh loop dapat berubah dengan waktu, dan Sudut antara B dan garis normal penampang kumparan (Serway \& Jewett, 2004).

\section{Hasil Dan Pembahasan}

\section{Medan Magnet Bumi dan Sistem Navigasi Migrasi Burung}

Dalam bermigrasi, burung tergantung dengan medan magnet bumi. Bahan magnetik tampaknya merupakan kandidat yang layak untuk dapat menjelaskan bagaimana intensitas sense bisa bekerja. Beberapa penelitian telah memperoleh dan atau mengkatalogkan bukti untuk mendukung bagaimana mekanisme ini dapat bekerja pada tingkat saraf dan seluler (Brian K. Taylor, 2016). Sejumlah eksperimen perilaku dan fisiologis menunjukkan bahwa beberapa hewan menggunakan intensitas magnetik sebagai bagian dari perangkat navigasi mereka (Taylor, 2016).

Selain burung, banyak spesies ngengat nokturnal melakukan migrasi jarak jauh yang spektakuler di malam hari. Setiap musim semi, miliaran ngengat Bogong (Agrotis infusa) keluar dari kondisi panas di berbagai wilayah Australia tenggara dengan melakukan migrasi terarah lebih dari $1.000 \mathrm{~km}$ ke sejumlah gua dingin di Pegunungan Alpen Australia, yang secara historis digunakan untuk merestorasi selama musim panas. Melalui sebuah eksperimen diperoleh data bahwa ngengat Bogong dapat merasakan medan magnet Bumi dan menggunakannya bersama dengan landmark visual untuk mengarahkan penerbangan migrasi. Dengan menambatkan ngengat yang bermigrasi dalam simulator penerbangan luar ruangan, ditemukan bahwa arah penerbangan mereka berubah secara terprediksi ketika tengara visual yang dominan dan medan magnet bumi yang alami disatukan, tetapi ngengat tersebut menjadi bingung dalam beberapa menit ketika kedua isyarat ini diganggu. Dengan demikian, disimpulkan bahwa ngengat Bogong, seperti halnya burung yang bermigrasi secara nokturnal, dapat menggunakan indera magnetis (Dreyer, 2018)

Burung menggerakkan kepalanya untuk mendeteksi arah medan magnet, dan penelitian yang dilakukan di sistem saraf burung menunjukkan bahwa burung dapat "melihat" medan magnet. Mata kanan burung migran mengandung protein fotoreseptif yang disebut cryptochrome. Sel-sel protein aktif setiap petang menjelang saat burung tersebut tidak dapat mengandalkan cahaya untuk melihat benda-benda di sekitarnya. Protein ini diketahui 
berperan dalam mengatur jam biologis, seperti pengaturan tahap pertumbuhan pada tanaman dan waktu kawin.

Cahaya merangsang molekul-molekul yang ada di dalam cryptochrome untuk menghasilkan elektron bebas yang berinteraksi dengan medan magnet bumi, sehingga memberikan informasi tentang arah. Cryptochrome berfungsi sepeti kompas yang digunakan sebagai penunjuk arah. Para peneliti sebelumnya mengira cryptochrome tidak memiliki banyak keuntungan bagi manusia sehingga tidak dapat mengenali medan magnet seperti burung. Karenanya, manusia butuh patokan atau perangkat Global Positioning Satelite (GPS) untuk mengetahui arah. Saat ini ilmuwan mengetahui bahwa cryptochrome pada manusia berfungsi sebagai jam molekul, bukan sebagai kompas.

Elektron dalam molekul cryptochrome saling terkait. Medan magnet bumi menyebabkan elektron bergoyang. Reaksi kimiawi untuk merespons goyangnya elektron tersebut membuat burung dapat melihat medan maget dalam warna-warni. Peter Hore dari Universitas Oxford dapat mengatur konsentrasi radikal bebas sesuai medan magnet yang dipaparkan. Ia berpendapat, cryptochrome pada burung mungkin diaktifkan cahaya biru yang muncul saat senja dan mulai bekerja dengan mekanisme pelepasan radikal bebas untuk melihat medan magnet bumi (Foley et al, 2011).

\section{Medan Listrik dan Pergerakan Ikan Hiu dalam Mencari Mangsa}

Hewan dengan sistem navigasi yang mengandalkan konsep medan listrik adalah hiu. Ratusan ribu organ electroreceptor (disebut Ampullae Lorenzini) di dalam tubuh ikan hiu, menyebabkan hiu memiliki sensitivitas listrik (Fields, 2007). Hiu kepala martil memiliki sensitivitas listrik terbesar di antara jenis hiu yang lain. Karena memiliki sensitivitas listrik inilah, hiu dapat mendeteksi sinyal dari setengah miliar volt tegangan listrik dari hewan lain. Oleh sebab itu hiu dapat dengat tepat menangkap mangsa, ketika memperoleh makanan. Ampullae Lorenzini mendeteksi medan listrik yang dihasilkan oleh hewan bawah air lainnya. Hiu menggunakan deteksi internal mereka seperti perangkat GPS. Hal ini membantu hiu untuk menyesuaikan diri dengan arus laut yang bergerak dalam medan magnet bumi.

Sebuah eksperimen perilaku hiu telah dilakukan oleh Kalmijn (Hopkins, 2010) yang mengungkapkan pentingnya electroreception dalam passive electrolocation of prey (penentuan lokasi mangsa berbasis medan listrik). Studi dilakukan di penangkaran hiu spotteddogfish Scyliorhinus canicula yang mampu mendeteksi secara akurat keberadaan mangsa berupa seekor flatfish dan Pleuronectes platessa yang terkubur di bawah pasir. Sebagai bukti bahwa hiu dipandu oleh sinyal listrik dalam mencari mangsa, eksperimen dilanjutkan dengan mengubur suatu elektroda di bawah pasir untuk menggantikan mangsa, dan hasilnya ketika hiu terhubung ke frekuensi rendah sumber arus $4 \mathrm{~mA}$, hiu melakukan serangan. Berdasarkan ujicoba ini dapat disimpulkan bahwa hiu memiliki preferensi untuk menyerang elektroda (Hopkins, 2010).

\section{Gelombang Bunyi dan Mekanisme Kelelawar dalam Mengenali Lingkungan}

Kelelawar mampu terbang di malam hari yang gelap-gulita tanpa mengalami gangguan yang berarti. Padahal diketahui bahwa mata kelelawar mengalami disfungsi (pelemahan fungsi). Untuk menavigasi dan berburu serangga dalam kegelapan total, kelelawar telah memiliki sistem akustik remotesing yang melampaui semua yang dibangun oleh manusia. Kelelawar dapat terbang di malam hari dengan kecepatan tinggi menghindari semua rintangan di jalur mereka dan dapat mendeteksi dan melacak serangga kecil dari beberapa meter jauhnya. Laring kelelawar menghasilkan suara ultrasonik, pada frekuensi antara 10 dan $150 \mathrm{kHz}$. Sebagai perbandingan, seseorang hampir tidak dapat mendeteksi suara pada frekuensi $20 \mathrm{kHz}$. Suara diproyeksikan melalui saluran vokal dan mulut terbuka atau hidung dalam bentuk pulsa dengan kecepatan 20-30 pulsa per detik (Gambar 3). Refleksi dari pulsa sonar kelelawar menentukan bentuk, lokasi, dan jarak objek di sekitarnya.

Mekanisme untuk memahami keadaan lingkungan dengan bantuan bunyi gema (echo) sebagaimana yang dimiliki oleh kelelawar sering disebut sebagai Echolocation (Ekolokasi). Gambar 7 menunjukan tentang mekanisme kelelawar mengenali 
lingkungannya dengan menggunakan sistem sonar.

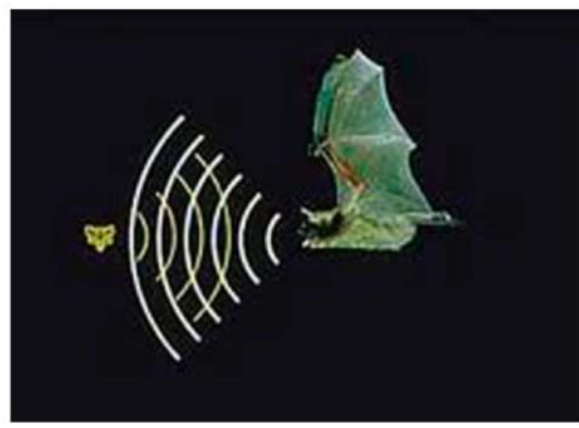

Gambar 6. Echolocation pada kelelawar (Klemas, 2012)

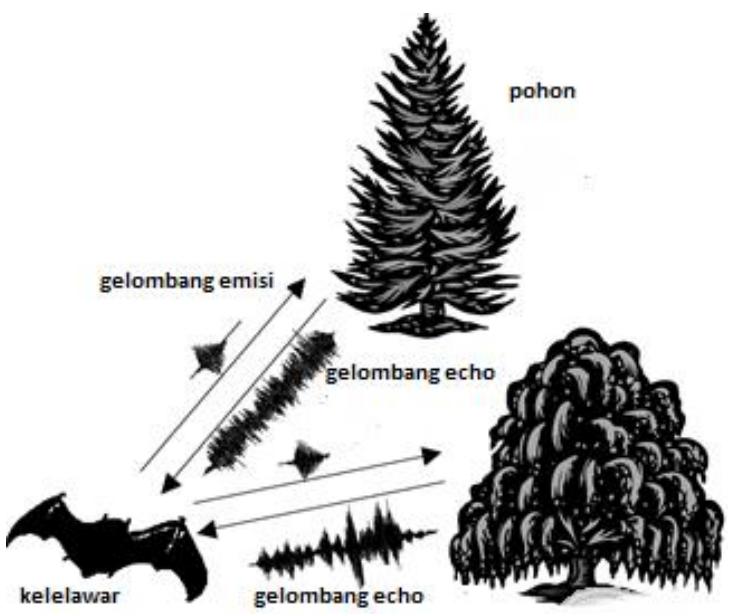

Gambar 8. Mekanisme Kerja Sistem Sonar

Kelelawar mengeluarkan bunyi pada frekuensi tinggi (emission), kemudian bunyi tersebut "menumbuk" pohon, sebagian bunyi akan memantul kembali (echo), kemudian ditangkap oleh telinga kelelawar. Tiap benda akan memantulkan bunyi echo dengan karakteristik yang berbeda. Perbedaan karakteristik bunyi echo tersebut yang digunakan oleh kelelawar untuk mengetahui keberadaan dua pohon yang berbeda.

\section{Simpulan}

Berdasarkan kajian, disimpulkan: 1) Burung mampu melakukan migrasi antar benua karena memiliki Magnetoreception berupa
Cryptochrome suatu protein fotoreseptif pada mata burung yang dapat membaca medan magnet bumi untuk menentukan koordinat/posisi, 2) Ikan hiu memiliki Electroreception berupa ampulla lorenzini yang dapat menangkap medan listrik dari hewan mangsa sebagai petnjuk dalam menemukan sumber makanan, 3) Kelelawar mampu terbang di malam hari dalam kedaan mata yang mengalami disfungsi karena pemanfaatan sistem sonar, yaitu upaya mngenali lingkungan dengan mengidentifikasi pola gelombang pantul (Echolocation)

\section{Daftar Pustaka}

Dormy. (2006).The origin of the Earth's magnetic field: Fundamental or environmental research? Europhysics news 37(2):22-25

Dreyer et al,. (2018). The Earth's Magnetic Field and Visual Landmarks Steer Migratory Flight Behavior in the Nocturnal Australian Bogong Moth. Current Biology Volume 28, Issue 13, 9 July 2018, Pages 2160-2166.e5

Fields, Douglas. (2007).The Sharks Electrics Sense: An astonishingly sensitive detector of electric fields helps sharks zero in on prey. SCIENTIFIC AMERICAN, INC

Fogarty and Pete (2010). How to Integrate the Curricula. Heidi Hayes Jacobs Publishers.

Foley, et al. (2011).Human cryptochrome exhibits light-dependent magnetosensitivity. Nature Communications volume2, Article number: 356 (2011)

Hopkins. (2010). A biological function for electroreception in sharks and rays. Journal of Experimental Biology 213(Pt 7):1005-7

Serway \& Jewett. (2004). Physics: For Scientists and Engineers 6TH EDITION. Brooks/Cole Publishing Co

Taylor. (2016). Validating a model for detecting magnetic field intensity using dynamic neural fields. Journal of Theoretical Biology Journal of Theoretical Biology 408 (2016) $53-65$

Victor V. Klemas, (2013),"Remote sensing and navigation in the animal world: an overview", Sensor Review, Vol. 33 Iss: 1 pp. $3-13$

Young \& Freedman. (2016). University Physics with Modern Physics, 14th Edition. California: Pearson 